\title{
Long-term assessment of renal function following nephrectomy for stage I renal carcinoma
}

\author{
H.B. GROSSMAN, D. SOMMERFIELD, J.W. KONNAK and J. BROMBERG* \\ Section of Urology, Department of Surgery, and *Department of Biostatistics, University of Michigan, Ann Arbor, Michigan. USA
}

Objective To evaluate the impact of nephrectomy on renal function in people who are potential candidates for nephron sparing surgery, i.e. partial nephrectomy.

Patients and methods $A$ retrospective analysis was carried out of 109 patients ( 35 women, 74 men) who had undergone a nephrectomy for stage I renal carcinoma at the University of Michigan between 1960 and 1979. All patients had a functioning contralateral kidney and had undergone at least one post-operative serum creatinine evaluation. Statistical analysis was by Pearson's correlation coefficient.

Results One individual developed a transitional cell carcinoma in the remaining renal pelvis and was treated with nephroureterectomy. No other patient progressed to dialysis. Five patients had post-operative serum creatinine levels from 221 to $354 \mu \mathrm{mol} / \mathrm{l}$, one of whom had undergone both a nephrectomy and a partial nephrectomy for bilateral renal tumours. The remaining four had renal disease including diabetes, hypertension, pyelonephritis and renal artery stenosis. There was a strong association between pre-operative and post-operative serum creatinine values.

Conclusion Patients with low stage renal tumours and a normal contralateral kidney are at low risk of progression to renal failure.

Keywords Renal function, nephrectomy, creatinine

\section{Introduction}

The most commonly employed treatment for renal cancer continues to be nephrectomy. This method of treatment offers the advantage of wide local excision but sacrifices some normal renal parenchyma. Individuals with a normal contralateral kidney do not appear to suffer acute problems from this method of therapy. However, the potential for adverse effects in patients with compromised renal reserve or a predilection for bilateral neoplasms, e.g. von Hippel-Lindau disease, has resulted in the exploration of alternative methods of therapy. The successful application of partial nephrectomy in this patient population has led to its use in selected individuals with small tumours and a normal contralateral kidney. One important factor in choosing between radical and partial nephrectomy in a patient with a small solid renal mass and a normal contralateral kidney is the long-term effect of losing a renal unit. We performed a retrospective analysis of patients who had undergone radical nephrectomy to determine the long-term outcome of this surgery on their renal status.

\section{Patients and methods}

Between 1960 and 1979165 patients underwent surgical excision of stage I renal carcinomas at the University

Accepted for publication 8 December 1993 of Michigan. Criteria for inclusion in this report included a nephrectomy, a functioning contralateral kidney and at least one follow-up creatinine evaluation after discharge from the hospital. From the initial population. 109 patients (35 women, 74 men) met these eligibility criteria and form the basis of this report. Serum creatinine measurements were not regularly obtained in all patients. For those individuals with sporadic values, renal function was assumed to have remained stable from the time of surgery or previous post-operative serum creatinine evaluation to the most recent evaluation. Follow-up is defined as the time interval from nephrectomy to the most recent serum creatinine evaluation.

Association between pre-operative and post-operative serum creatinine values was assessed using Pearson's correlation coefficient. The same method was used to determine whether there was an association between post-operative serum creatinine values and possible confounding variables such as follow-up time, age and year of nephrectomy. A $P$ value of $\leqslant 0.05$ was taken to indicate significance.

\section{Results}

One of the 109 individuals progressed to renal failure. This individual developed a transitional cell carcinoma in his remaining renal pelvis 10 months after the initial nephrectomy. After nephroureterectomy he was maintained on dialysis. 
The remaining 108 patients did not have any clinical disability related to loss of normal renal parenchyma. Follow-up ranged from $<1$ month to 23.5 years with a mean of 3.2 years. The median creatinine value at follow-up was $124 \mu \mathrm{mol} / \mathrm{l}$. At the most recent followup $70 \%$ of the patients had serum creatinine values of $\leqslant 133 \mu \mathrm{mol} / \mathrm{l}, 19 \%$ had values ranging from 141 to $177 \mu \mathrm{mol} / \mathrm{l}$, and $11 \%$ had creatinine values $>177 \mu \mathrm{mol} / \mathrm{l}$. There were five individuals with followup serum creatinine values of $\geqslant 221 \mu \mathrm{mol} / \mathrm{l}$ (Table 1 ). One presented with bilateral synchronous renal tumours and underwent a unilateral nephrectomy and a partial nephrectomy. The others had medical conditions which may have contributed to their renal deterioration including diabetes, hypertension, chronic pyelonephritis, staghorn calculi and renal artery stenosis. Three individuals with follow-up serum creatinine values of $\geqslant 265 \mu \mathrm{mol} / \mathrm{l}$ had pre-operative values of 150,194 and $239 \mu \mathrm{mol} / \mathrm{l}$.

Follow-up creatinine is plotted against follow-up time in Fig. 1. If all patients are considered, there was a marginally significant tendency for patients with higher creatinine values to be followed for a short period of time $(r=-0.19, P=0.05)$. There were three highly influential observations in individuals with recent creatinine values of $\geqslant 265 \mu \mathrm{mol} / \mathrm{l}$. When these observations were excluded, the correlation coefficient was reduced to -0.14 and its significance fell to $P=0.15$. There was a slight but statistically significant association between creatinine value and age $(r=0.21, P=0.03)$. Creatinine values were significantly lower for women than for men (women: $\overline{\mathrm{x}}=1.3, \mathrm{SE}=0.05$; men: $\overline{\mathrm{x}}=1.6, \mathrm{SE}=0.06 ; P=$ $0.007)$. None of the 35 women had a creatinine value that exceeded $177 \mu \mathrm{mol} / 1$ while $16 \%$ of the 74 men had creatinine values of that magnitude. There was no statistically significant association between the most recent creatinine value and the year of nephrectomy $(r=0.15, P=0.13)$.

Both pre-operative and follow-up serum creatinine measurements were available for 87 patients. There was a strong association (Fig. 2) between pre-operative and follow-up serum creatinine values $(r=0.63, P<0.001)$.

\begin{tabular}{|c|c|c|c|c|}
\hline $\begin{array}{l}\text { Post-operative } \\
\text { creatinine } \\
\text { ( } \mu \mathrm{mol} / \mathrm{l})\end{array}$ & $\begin{array}{l}\text { Pre-operative } \\
\text { creatinine } \\
(\mu \mathrm{mol} / \mathrm{l})\end{array}$ & $\begin{array}{l}\text { Age } \\
\text { (years) }\end{array}$ & $\begin{array}{l}\text { Follow-up } \\
\text { (months) }\end{array}$ & Medical problems \\
\hline 354 & 194 & 67 & 7 & Diabetes and hypertension \\
\hline 274 & 150 & 65 & 6 & $\begin{array}{l}\text { Bilateral tumours, nephrectomy and } \\
\text { partial nephrectomy }\end{array}$ \\
\hline 265 & 239 & 55 & 17 & $\begin{array}{l}\text { Chronic pyelonephritis and } \\
\text { bilateral staghorn calculi }\end{array}$ \\
\hline 230 & 124 & 75 & 14 & $\begin{array}{l}70 \% \text { stenosis of remaining } \\
\text { renal artery }\end{array}$ \\
\hline 221 & 133 & 63 & 23 & Diabetes and hypertension \\
\hline
\end{tabular}

Table 1

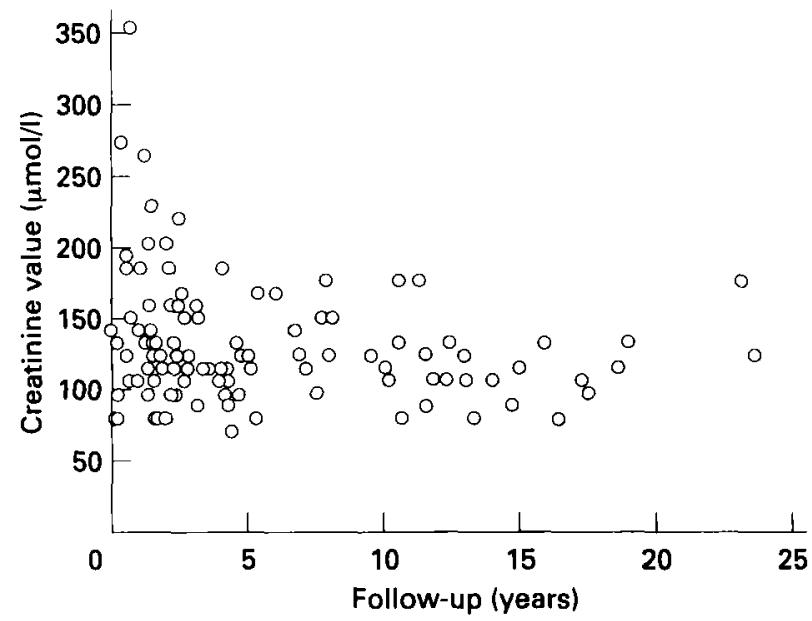

Fig. 1. Serum creatinine following nephrectomy for stage I renal carcinoma. Creatinine is expressed for each patient at the longest follow-up time.

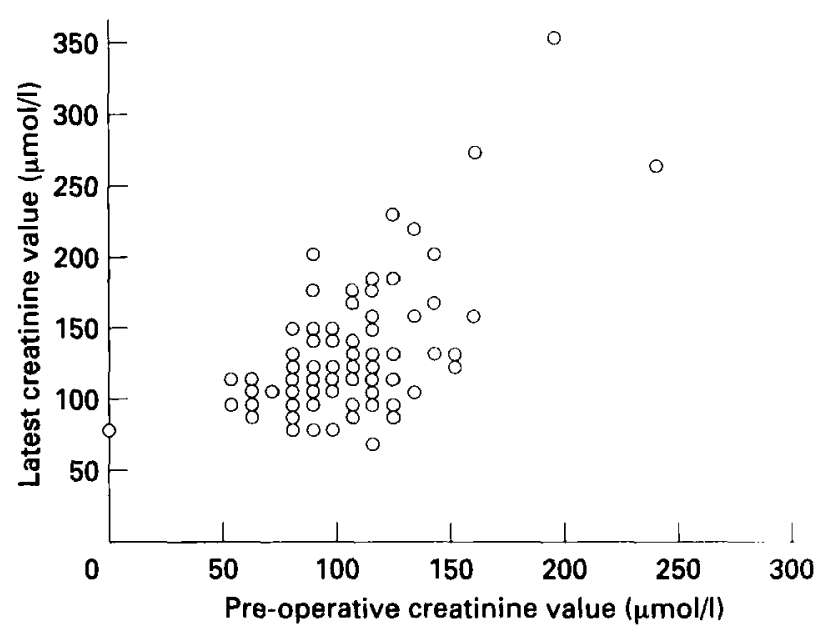

Fig. 2. Pre-operative versus most recent post-operative serum creatinine values. 
The strength of this association persisted even when the individuals who had post-operative creatinine values of $\geqslant 265 \mu \mathrm{mol} / \mathrm{l}$ were excluded from the analysis.

\section{Discussion and conclusions}

Nephrectomy continues to be the most common surgical approach to the treatment of localized renal carcinoma. However, increasing attention is being focused on the role of parenchyma sparing approaches, particularly partial nephrectomy, as an alternative form of therapy. Partial nephrectomy and/or tumour enucleation have been successful in patients with one functioning kidney and those at high risk of bilateral disease, e.g. patients with von Hippel-Lindau disease [1]. The effectiveness of parenchyma sparing surgery in this clinical setting has led to the use of partial nephrectomy in patients with low stage tumours and a normal contralateral kidney [2-5]. Although the preservation of renal parenchyma is intuitively appealing, the employment of this strategy in patients with low stage renal carcinoma and a normal contralateral kidney should be based on a rational evaluation of the risks and benefits. The major benefit of this approach is the preservation of normal renal parenchyma. An aura of controversy surrounds the hypothesis that glomerular hyperfiltration occurring after nephrectomy contributes to long-term renal deterioration. However, the major disadvantage of less than complete renal excision is the increased risk of local recurrence. While theoretically the probability of local recurrence is high $[6,7]$, clinical data suggests that the true incidence of this phenomenon in appropriately selected individuals is $6 \%$ or less [1-5]. This is similar to the $7 \%$ incidence of multifocal renal cancer found when nephrectomy specimens are serially sectioned [8].

A retrospective evaluation was performed of 109 individuals who had adequate renal function and a nephrectomy for stage I renal cancer. Only one person $(0.9 \%)$ required dialysis. This individual developed a transitional cell carcinoma in the contralateral kidney which was treated with nephroureterectomy. Postoperative serum creatinine strongly correlated with the pre-operative values. Five patients had a post-operative serum creatinine $\geqslant 221 \mu \mathrm{mol} / \mathrm{l}$. One of these patients presented with bilateral synchronous renal tumours and was treated with a nephrectomy and partial nephrectomy. The remaining four patients had medical diseases including diabetes, hypertension and renal artery stenosis, which may have contributed to their deterioration in renal function.

The excellent long-term renal function in the patients reported here is similar to the experience reported by Wishnow et al. [9]. In their series of 56 patients who were followed for more than 115 months after radical nephrectomy, only two individuals had a serum creatinine $>141 \mu \mathrm{mol} / \mathrm{l}$. The individual with a creatinine value $>177 \mu \mathrm{mol} / \mathrm{l}$ also had a predisposing medical condition, i.e. diabetes. Novick et al. reported on a series of 12 patients who had undergone partial nephrectomy in a solitary kidney [10]. In this group of patients who had a relatively small volume of normal parenchyma remaining (25-75\% of a single kidney), progressive renal insufficiency requiring dialysis occurred in only two patients. While mild to moderate proteinuria was common, the remaining patients had stable renal function with only two having serum creatinine levels $>177 \mu \mathrm{mol} / \mathrm{l}$ (239 and $248 \mu \mathrm{mol} / \mathrm{l})$. Higashihara et al. presented a large series of patients who had nephrectomy or congenital renal agenesis [7]. This group also demonstrated that urinary protein excretion increases with time following nephrectomy. However, despite this laboratory abnormality, these patients did not develop increases in serum creatinine or hypertension and did not develop clinical problems related to renal deterioration.

There is little controversy regarding partial nephrectomy in individuals who have a renal neoplasm in a solitary kidney or a poorly functioning contralateral kidney and those individuals at risk of multifocal neoplasia, i.e. von Hippel-Lindau disease. There continues to be controversy regarding the appropriateness of partial nephrectomy in individuals with low stage renal carcinomas and a normal contralateral kidney. The present data and that of others suggest that people with a normal contralateral kidney rarely suffer ill consequences as a result of their nephrectomy and do not manifest a need for more renal parenchyma. This global statement may not be true for those at risk of medical renal disease, such as individuals with diabetes or hypertension. While partial nephrectomy may be the most conservative approach in this latter population, the widespread use of this technique in healthy individuals with renal neoplasms should await more data describing the risks of local recurrence in low stage renal cancer.

\section{References}

1 Novick AC, Zincke H, Neves RJ, Topley HM. Surgical enucleation for renal cell carcinoma. J Urol 1986; 135: 235-8

2 Van Poppel H, Claes H, Willemen P, Oyen R, Baert L. Is there a place for conservative surgery in the treatment of renal carcinoma? Br J Urol 1991; 67: 129-33

3 Provet J, Tessler A, Brown J, Golimbu M, Bosniak M, Morales P. Partial nephrectomy for renal cell carcinoma: indications, results and implications. J Urol 1991; 145: 472-6

4 Novick AC, Streem S. Montie JE et al. Conservative surgery 
for renal cell carcinoma: a single-center experience with 100 patients. J Urol 1989; 141: 835-9

5 Morgan WR, Zincke $H$. Progression and survival after renal-conserving surgery for renal cell carcinoma: experience in 104 patients and extended follow-up. J Urol 1990; 144: 852-8

6 Blackley SK, Ladaga L, Woolfitt RA, Schellhammer PF. Ex situ study of the effectiveness of enucleation inpatients with renal cell carcinoma. J Urol 1988; 140: 6-10

7 Marshall FF, Taxy JB. Fishman EK, Chang F. The feasibility of surgical enucleation for renal cell carcinoma. J Urol 1986; 135: 231-4

8 Cheng WS, Farrow GM, Zincke $H$. The incidence of multicentricity in renal cell carcinoma. J Urol 1991; 146: $1221-3$
9 Wishnow KI, Johnson DE, Preston D. Tenney D. Long-term serum creatinine values after radical nephrectomy. Urolog! 1990; 35: 114-6

10 Novick AC, Gephardt G, Guz B. Steinmuller D. Tubbs RR. Long-term follow-up after partial removal of a solitary kidney. New Engl J Med 1991; 325: 1058-62

\section{Authors}

H.B. Grossman, MD, Professor and Interim Head. D, Sommerfield, BSN, Clinical Care Coordinator. J.W. Konnak, MD, Professor.

J. Bromberg, MS, PhD, Assistant Research Scientist. Correspondence: Professor H.B. Grossman, 1500E. Medical Center Drive, Ann Arbor, MI 47109-0330, USA. 